\title{
Colecionismo, colonialismo e museus: Ensaio sobre duas exposições
}

Laura Pérez Gil

(UFPR)
Musée du quai Branly. Kanak, l'art est une parole. Exposição temporária (do 15 de outubro de 2013 e o 26 de janeiro de 2014). Paris.

The Museum of Ethnography. With the World in the Backpack. Exposição permanente (desde 2002 até o presente). Estocolmo.

Começarei esta reflexão com uma anedota. Durante uma visita ao Museu de Etnografia de Estocolmo, entrei numa sala escura, onde diversas telas exibiam, de forma repetitiva, filmagens de rituais africanos nos quais os participantes dançavam ao som de tambores. O tambor, como agente ritual, parecia ser o protagonista da sala. Nela havia uma pequena arquibancada semicircular, como de um teatro romano, e alguns tambores de diferentes tamanhos e formas, disponíveis para quem quisesse experimentar. Vazia a sala - como de resto as outras da exposição onde havia cruzado com duas ou três pessoas até o momento -, sentei-me na escuridão. Alguns minutos depois, entrou outra visitante que logo se aproximou de mim com o braço estendido para tocar-me. Mostrei a minha surpresa, ela riu e se desculpou dizendo que achava que era parte da exposição. De repente, me vi jogada, qual Alice, do outro lado do espelho, ou, melhor dizendo, do outro lado do expositor. Sendo etnóloga e curadora em outro museu, a ideia não deixava de ser cativante. De resto, era exatamente isso que a exposição do museu sugeria. Casualidade? 
Após algumas décadas banidos dos interesses teóricos e etnográficos da antropologia, os objetos voltam com força à cena da produção do pensamento antropológico e, junto, a reflexão sobre os museus. A reaparição no campo intelectual da antropologia contemporânea, e mais concretamente da etnologia, dos objetos e dos espaços constituídos para a sua guarda, conservação e exibição, veio marcada pela crítica pós-moderna às práticas de colecionismo e de musealização das coleções etnográficas (Clifford 1988, Fabian 2001, Thomas 1991). Os museus das grandes metrópoles europeias e norte-americanas parecem ser a materialização do pecado colonial; carregam em si a marca da assimetria - social, política, econômica - que marcou as relações dos impérios com as populações cujos territórios, de uma ou outra forma, ocuparam.

As interações, seja qual for a sua natureza, ocorridas no marco do contexto colonial tiveram como um dos seus eixos centrais a circulação de coisas. Se tanto europeus como os diversos povos nativos se apropriaram e ressignificaram os objetos alheios, tornando-os um emaranhado de significados, no caso dos primeiros uma das formas destacadas dessa apropriação foi o colecionismo. Este foi motivado por uma mistura de curiosidade, de busca pelo desenvolvimento do conhecimento científico e da necessidade de justificar e enaltecer os projetos e "sucessos" da expansão imperialista (Thomas 1991).

Dessa forma, o colecionismo de objetos dos povos contatados, primeiro, e dominados, depois, se erigiu em agente destacado do colonialismo. Ocorreu em ocasiões por compra ou escambo, mas não em menor medida sob a forma de roubo e esbulho. São, por exemplo, paradigmáticas as confissões de Michel Leiris sobre os procedimentos fraudulentos usados durante a Missão Dacar-Djibuti ao se deparar com a negativa das populações que visitavam em lhes ceder as sagradas pinturas de uma igreja ou a estatueta de um ser venerado (Leiris 2007).

Inicialmente "curiosidades", os objetos que iam engrossando as coleções europeias se transformariam, posteriormente, em objetos etnográficos e/ou obras de arte na medida em que circulavam, e eventualmente se fixavam, em museus, galerias de marchands ou leilões. Seja como for, eram considerados, invariavelmente marcadores do Outro, suas extensões metonímicas ou a materialização daquilo que os caracterizava e definia: o canibalismo, a selvageria, ou a idolatria num primeiro momento (Thomas 1991); as particularidades estéticas e culturais, posteriormente. O próprio conceito de "objeto etnográfico", produto da dimensão científica do afã colecionista, aponta precisamente para o fato de se considerar que ele traz em sua materialidade informações sobre os costumes e sentidos do coletivo humano que o produziu: para que servem esses objetos, como se usam, quais são os métodos e materiais de fabricação, qual é o significado dos motivos que os adornam, o que simbolizam? Em sua condição de objetos etnográficos, eles foram tidos como testemunhas objetivas da vida cultural (Clifford 1988).

Assim, geralmente, as exposições nos museus etnográficos nos falam dos outros através dos seus objetos, ou podemos colocar essa questão em outros termos: frequentemente, as narrativas museográficas construídas com esses objetos pretendem falar exclusivamente sobre seus proprietários originais. Considerase que nos falam sobre os Outros porque são, unicamente, objetos etnográficos; porém, para construi-los 
enquanto tais foi necessário reposicioná-los conceitualmente. Para tanto, de um lado, são congelados no momento imediatamente anterior a sua aquisição: sua vida social (Appadurai 2008), no momento da aquisição e posterior a ela, é totalmente apagada. O fato de o objeto passar, a partir de então, por um processo de transformação, adequação, neutralização ou higienização estética, moral e conceitual (Snoep 2005, Murphy 2013) é ignorado. Aparentemente, carece de importância na maior parte dos casos. De outro, se desconsidera o fato de que tanto os princípios estéticos, teóricos e ideológicos do pesquisador e a instituição que o financia, como as circunstâncias econômicas e políticas do contexto no qual se realiza a "coleta", são fatores que participam no processo de transformar uma coisa em objeto etnográfico - ou em curio, outrora - e torná-la, portanto, passível de coleta (Fabian 2001). E, entretanto, não apenas o que se coleta, mas como se faz, por que, por quem, sob quais circunstâncias, etc, são aspectos que passam também a constituir o objeto musealizado, enquanto produto complexo desse conjunto de relações e significados diversos. Como vários autores têm salientado, o próprio contexto colonial, ou qualquer outro de coleta, desencadeia processos que afetam os objetos, seu significado e a sua produção. Não faltam exemplos na literatura.

Em torno do 1800 os europeus introduziram nas ilhas Fiji os dentes de baleia como elemento de troca por outros produtos nos quais estavam interessados. Os dentes, por sua vez, passaram a ser usados pelos fijianos para a fabricação de um tipo de objeto - chamado tabua e usado pelos chefes fijianos em diversos contextos cerimoniais - que se pode encontrar caracterizado como "tradicional" em diversos museus (Thomas 1991). Outro caso ilustrativo é o das estatuetas cobertas de pregos, minkisi, elaboradas pelas populações do Congo para diversas finalidades, entre elas o combate à bruxaria, e que representavam o paradigma do "fetiche" para os europeus. No final do século XIX, ante o temor de sua desaparição e respondendo à lógica salvacionista tão recorrente na história da antropologia, a coleta se incrementou; paradoxalmente, os minkisi não pareciam estar em "vias de extinção": de um lado, o incremento da mortalidade gerado pelas condições instauradas no contexto colonial tinha incentivado o aumento da sua produção e diversificado suas formas e modalidades; de outro, a demanda dos museus promoveu igualmente um aumento da produção, criando-se dois mercados paralelos, um internacional e outro local (Snoep 2005). Circunstâncias coloniais e agentes de coleta tiveram um impacto nada desprezível nos contextos e formas de elaboração, assim como nos significados que os objetos comportam, e esses contextos relacionais devem ser objeto de reflexão museológica através, por exemplo, de exposições (Price 2010a).

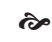


O presente ensaio é uma reflexão sobre duas exposições que visitei em 2013 e 2014'. O que ambas têm em comum é o fato de incorporarem nas narrativas expositivas os contextos nos quais os objetos foram coletados. Mais do que expor "culturas", expõem-se contextos relacionais marcados, principalmente, pela ordem colonial.

A primeira foi a exposição Kanak, l'art est une parole, em exibição no Musée du Quai Branly (MQB) entre o 15 de outubro de 2013 e o 26 de janeiro de 2014. O espaço de exibição foi a Galerie Jardin, o principal espaço expositivo $\left(2000 \mathrm{~m}^{2}\right)$ para exposições temporárias nesse museu, onde nessa ocasião foram exibidas 320 peças. Como é de praxe no MQB, foram lançadas duas publicações de exposição: um catálogo propriamente falando, publicação mais completa e de maior fôlego, de 340 páginas (Boulay e Kasarhérou 2013), e uma outra em um número especial da revista Télérama dedicado à exposição (Cachon org. 2013).

A segunda exposição é uma das que está em exibição permanente no Museum of Ethnography de Estocolmo, cujo título, "With the World in the Backpack", remete às conexões estreitas entre viagens e coisas. A exposição está formada por várias seções, como descreverei mais adiante. Foi inaugurada em 2002 e teve acréscimos e/ou reformulações de algumas vitrines em 2009 e 2011. Os curadores da exposição são Leif Länsikylä e Irene Svensson, e a responsável pela proposta museográfica, Anna Asker. Na exposição são exibidos 1109 elementos, entre fotografias, documentos e objetos, e conta com um catálogo (Östberg ed. 2002).

A exposição Kanak foi realizada para marcar simbolicamente o início do período, entre 2014 e 2018, em que deveria ser organizado o referendum de autodeterminação sobre a independência da Nova Caledónia em relação à República francesa. Assim, ela esteve em exibição em Paris em 2013 e, posteriormente, seria trasladada a Nouméa (Nova Caledónia) onde ficaria por vários meses em 2014 (Cachon 2013a). A exposição girava em torno de dois grandes princípios que articulavam circuitos paralelos e complementares: de um lado, afirmava-se, nos textos apresentados ao público, que a exposição foi construída a partir das categorias culturais e visão de mundo kanak: são eles mesmos que falam sobre si; de outro lado, que nela confluem os olhares recíprocos entre europeus e Kanaks². Esta dimensão intercultural da proposta expositiva se reflete na equipe curatorial, formada por Emmanuel Kasarhérou, de origem kanak e ex-diretor do centro cultural Jean-Marie Tibajou, e Roger Boulay. Esse último vem realizando desde 1979 o “inventário do patrimônio kanak disperso", financiado pelo governo da Nova Caledônia, e que tem por objetivo fazer um levantamento de todos os materiais kanak localizados em acervos de museus. Não se trata de um projeto de caráter exclusivamente museográfico, senão que alude ao peso político dos objetos. Parece destinado a tentar contra-arrestar o efeito desintegrador que o colecionismo ocidental teve durante o período colonial. A dispersão dos objetos kanak foi a um só tempo instrumento e consequência do processo colonizador; “quanto mais afluíam os objetos a Ocidente, mais os Kanak eram esmagados" (Cachon 2013b). 
$\mathrm{Na}$ exposição, o visitante era recebido por umas alongadas esculturas em madeira, que formavam uma pequena floresta de varas com rostos que remetiam às máscaras tradicionais. A elas tinham sido amarrados pedaços de tecidos coloridos e estampados. Segundo Roger Boulay ${ }^{3}$, esses tecidos foram trocados, em uma cerimônia de intercâmbio que reproduziu àquelas da tradição kanak, entre a equipe do MQB e o grupo vindo da Nova Caledônia para a inauguração da exposição. A dimensão dialógica é, assim, marcada desde o início da exposição.

A seguir, o visitante se adentrava num universo de objetos que, tanto nos primeiros tempos da colônia como nos dia de hoje, fascinaram e continuaram fascinando o Ocidente: as máscaras de dolente, de narizes proeminentes, grandes bocas mostrando os dentes brancos, longas barbas e penteados feitos com cabelos humanos; as "moedas", elaborados e valiosos objetos feitos de conchas; os bambus gravados, instrumentos musicais decorados com delicados motivos, alguns dos quais ilustravam cenas da vida colonial; as escultóricas flechas ou remates, que antigamente eram envergadas no topo do teto cônico da Casa dos Homens e que constituem um dos elementos mais representativos da cultura kanak; as esculturas em madeira, representações dos ancestrais, que margeavam a entrada da Casa dos Homens; as bordunas de diferentes formas; ou um significativo "machado-ostensório", coletado na expedição de Entrecasteaux, confiscado posteriormente pelos holandeses e que teve um tortuoso percurso até chegar a fazer parte das coleções de um museu francês (Cachon 2013c). Esse universo de objetos, expostos de forma a realçar suas qualidades plásticas e estéticas, como é a marca do MQB (Price 2010b), colocava a ênfase na dimensão cerimonial, e principalmente masculina, da tradição kanak. A etnografia de Leenhardt sobre a pessoa kanak - por outro lado, um dos conceitos chave da exposição - parecia ter-se materializado. A sensação que experimentava o visitante de se submergir nesse mundo ritual, ancestral, exótico e sagrado, era promovida e reforçada através de diversos recursos expográficos: uma atmosfera escura remetendo ao segredo, com o predomínio do negro como fundo sobre o qual as peças expostas eram realçadas através de luzes individualizantes; um ambiente sonoro criado com músicas e falas kanak; suportes quase invisíveis para as peças, criando a sensação de estarem quase flutuando. Mais do que como objetos etnográficos, eram apresentados ao público como objetos de arte.

Após uma primeira parte, que se ajustava às expectativas que os visitantes costumam ter sobre uma exposição etnográfica, o circuito expositivo se debruçava sobre a realidade colonial. Em primeira instância, apareciam as ilustrações elaboradas pelos protagonistas dos primeiros contatos, com Cook à cabeça, que retratam os Kanak em um tom um tanto rousseauniano, apresentando cenas paradisíacas, com homens e mulheres seminus, mas profusamente ornamentados, desfrutando de uma natureza generosa, com abundante vegetação, regalando-se com frutos exóticos. Essa imagem contrastava com a caracterização da população nativa como selvagem, canibal, primitiva, idólatra, que iria predominar durante a maior parte do circuito dedicado à época colonial. O horror e a violência desse período estampam-se nos retratos dos Kanak junto às autoridades coloniais, nos quais é possível perceber a severidade, a falta de empatia e o 
desprezo que estas tinham em relação a uma população sobre a qual exerciam todo o peso do poder. 0 paroxismo da desumanidade colonial chega ao tratar das grandes Exposições Universais que ocorreram ao longo da segunda metade do século XIX e adentraram ainda nas primeiras décadas do XX. As fotografias e cartazes mostram um imaginário popular, mas que predominava também no âmbito científico e político, em que os Kanak são retratados como selvagens canibais, e que mostram o processo de humilhação, objetificação e animalização ao qual foram submetidos, como tantos outros povos na época, ao ser expostos para divertimento e para exaltação do empreendimento imperialista. A exibição na exposição desse material produzia uma espécie de jogo de espelhos, de deslocamento, em que a desumanização - a perda de condição humana enquanto condição moral - que outrora foi atribuída aos Kanak, era agora projetada sobre aqueles que lhes negaram a humanidade.

O tema das reivindicações independentistas permeia a exposição, embora apareça de forma mais expressiva no final do circuito. Uma figura central é a de Jean-Marie Tibajou, líder do Frente de liberação nacional kanak e socialista (FLNKS), impulsor de um movimento de revitalização cultural, criador do primeiro centro cultural kanak, e protagonista das negociações que desembocaram nos acordos de Matignon, que foi assassinado em 1988 após um período de diálogo impulsionado pelo presidente Michel Rocard (Cachon org. 2013). Uma obra composta de duas esculturas em madeira, cujo revelador título é "Os dois irmãos" (Les deux frères) e cujo autor é Jean-Philippe Tibajou, filho do líder, é uma homenagem a Jacques Lafleur e Jean-Marie Tibajou. Ambos foram os artífices do acordo que terminou com a guerra civil que assolou o arquipélago durante a década de 1980, inaugurando um tempo de paz. Outro objeto que remete ao movimento independentista é a bandeira kanak, costurada a mão pelas mulheres do FLNKS e que tem como seu motivo central uma flecha escultórica. Igualmente a figura do chefe Ataï, evocada especialmente num trecho da exposição destinado a tratar sobre a importância econômica, social e simbólica do inhame para os Kanaks, tem ressonâncias políticas, já que ele se tornou um ícone da resistência contra a colônia. Ataï desencadeou em 1877 uma rebelião contra os desmanes e as injustiças das autoridades coloniais francesas, que acabou com sua decapitação. Sua cabeça, enviada pouco depois à metrópole, foi conservada durante décadas no Musée de L'Homme e restituída a seus descendentes apenas em $2014^{4}$.

Num certo movimento circular, o trecho final do circuito expositivo deixa atrás a exibição dos contextos sociais, políticos e econômicos do povo kanak para dar lugar às manifestações artísticas, dessa vez contemporâneas. Como no início da exposição, a estética assume o protagonismo, seja através de objetos ou da palavra. Entre os objetos, destacam a inquietante escultura "L'homme lézard" (1992) de Dick Bone, e os belos "vestidos liberados" (robes liberés) produzidos por Stéphanie Wamitan. A autora se apropria dos vestidos que os missionários impuseram às mulheres kanak para ocultar os corpos que consideravam imorais porque os enxergavam como nus. Decorando essas roupas coloniais e repressoras com motivos eróticos, a artista subverte e contesta a lógica missionária. 
Quanto à palavra kanak, ela aparece de forma especialmente intensa e poderosa na performance, que o visitante pôde assistir através da projeção de um filme, do jovem artista Paul Wamo, que se define a si próprio como "clameur de mots". É uma das várias instâncias em que, ao longo da exposição, a palavra kanak chega ao visitante. Junto com outros artistas kanak, Paul Wamo compôs também o ciclo de espetáculos artísticos e culturais que foram apresentados no teatro Lévi-Strauss no MQB coincidindo com a exposição.

A exposição "With the World in the Backpack" não tem, da sua parte, o propósito de fazer chegar aos visitantes a voz de outros povos. Diferentemente da exposição do MQB, que expõe a complexidade das relações entre os povos kanak e francês (ou seus representantes coloniais, no caso desses últimos) ao longo da história, o Museu de Etnografia de Estocolmo opta por outra estratégia: ele inclui, ou melhor, coloca em primeiro plano os agentes dos processos de coleta de coisas que viriam a se tornar objetos musealizados. Esses objetos não são expostos como característicos de uma determinada cultura, mas enquanto elementos coletados num determinado contexto.

Assim, a exposição está constituída por vários segmentos, cada um dedicado a processos ou personagens suecos que em diferentes momentos históricos e com diferentes finalidades coletaram os objetos que hoje formam parte do acervo do museu. Viagens e viajantes e os objetos que levam, trazem, carregam, coletam, guardam... durante essas explorações, parecem ser o leitmotiv da exposição, o que é marcado tanto no título da mesma como em uma cenografia constituída por um velho armário guardavolumes ladeado de malas, mochilas, baús e bolsas de viagens diversas.

Os diferentes segmentos da exposição têm os seguintes títulos: "Carl von Linné's disciples -the Swedish Royal Academy of Sciences", "Adolf Erik Nordenskiöld", "Eric Mjöberg - skeleton collector", "The Congo Mission", “From pole to pole - Sven Hedin's trips", “Sten Bergman”, “Whose objects". Não detalharei todos eles; apenas farei descrições tentando evidenciar o que me parecem os argumentos que norteiam a narrativa da exposição.

O primeiro segmento sobre o qual me debruçarei, e que foi por onde iniciei a minha visita, é aquele dedicado ao naturalista e etnólogo Sten Bergman. O espaço expositivo está ocupado pelo que me pareceu ser a recriação da sala de estar - aquela do próprio Bergman? - onde há uma mesa redonda de madeira, um sofá, uma poltrona, um aparelho de rádio antigo, uma bola do mundo... Ao redor da sala, várias vitrines embutidas nas paredes de madeira cor mogno mostram objetos etnográficos da Nova Guiné, tais como máscaras de ancestrais, escudos, ornamentos e diversas figuras talhadas em madeira. Entre elas destaca uma caveira ornamentada asmat, que segundo o banco de dados online do museu ${ }^{5}$ foi confiscada por autoridades alemãs, embora não se ofereça mais informações sobre como finalmente chegou até o museu de Estocolmo e porque está associada a Bergman. Numa das vitrines, junto aos objetos etnográficos, há vários 
pássaros dissecados da região, assim como fotos de Sten Bergman em trabalho de campo e algumas das suas publicações. Ele tinha, ao que parece, mais interesse no trabalho ornitológico do que no etnográfico, e nessa ação coletora, os protetores penianos e narigueiras cumpriam antes o papel de comprovar a estadia entre povoações "extremadamente primitivas", como aventura o comentário do banco de dados do museu , do que um objetivo propriamente científico, o que resulta numa falta de documentação sobre esses objetos.

Outro dos espaços expográficos está dedicado aos discípulos de Carl von Linné. O expositor principal reproduz uma mobília, ela própria mecanismo classificador, constituída de múltiplas divisões, cada uma delas com um objeto, principalmente animais dissecados, partes e restos do universo zoológico e vegetal. O verde pastel escolhido como cor, os desenhos de plantas que o decoram, e a tipografia da expressão em latim que Ihe dá nome, "Systema Naturae", remetem à estética científica da época. Instrumentos usados pelos exploradores que trouxeram todos esses elementos das suas viagens científicas, assim como livros e desenhos por eles publicados completam o expositor. Frente a ele, no meio da sala, outro grande expositor de vidro tem no seu interior uma mesa antiga branca, sobre a qual se dispõem objetos etnográficos diversos e documentos, sugerindo o aspecto que poderia ter a sala de trabalho desses exploradores. No teto, a decoração reproduz o céu noturno estrelado, mais uma dimensão que era explorada cientificamente pelos protagonistas dessa seção. É certamente o cenário de personagens devotados à ciência. Qual o papel dos povos indígenas nesse contexto? A exposição sugere, não sei até que ponto proposital e criticamente, uma visão que estabelece uma relação de continuidade entre espécimes "naturais" e "culturais", ambos englobados pela Natureza. Os objetos etnográficos coletados são manifestações de "espécies humanas", que da mesma forma que as naturais, são objeto de classificação. Paralelamente à formulação da continuidade entre "espécimes culturais" e "espécimes naturais", sendo ambos objetos de pesquisa científica, é estabelecida uma relação discreta entre "espécimes naturais" e instrumentos de pesquisa. O que se expõe é a ideologia de uns homens que se vêm a si próprios como sujeitos que produzem conhecimento, e vêm os Outros como objetos de pesquisa, com um status equivalente a elementos da flora e da fauna. A exposição sugere que havia para esses cientistas uma parte da humanidade que estava mais para a Natureza do que para a Cultura.

Adolf Nordenskiöld e a expedição, que no último quarto do século XIX o tornou o primeiro a ter percorrido a passagem do Norte, são os protagonistas de outro dos trechos expositivos. Junto a uma maquete do baleeiro SS Vega, contra o fundo de uma imagem nórdica de mar, montanhas e gelo, uma multiplicidade de objetos inuit e de povoações siberianas são apresentados: roupas, armas, arpões, pequenas esculturas, antropomorfas e zoomorfas, de osso. Os objetos exibidos, um tanto aleatórios em seu conjunto (ao menos para quem não é especialista), são, antes de mais nada, testemunhas silenciosas, mas eloquentes, de uma façanha de conotações épicas que tornou Nordenskiöld um herói e que marcou a incorporação da Suécia - com atraso, porém com glória - à época das sociedades geográficas e das explorações científicas (Helmfrid 2004). O caráter científico da expedição do SS Vega é reforçado por meio do fornecimento de 
informações sobre os objetos expostos, que são aqui mais rigorosas e específicas do que em outras partes da exposição. Mas os objetos, exibidos contra as grandes fotografias que colocam em destaque o meio ambiente hostil, parecem cumprir também outra função: a de evidenciar as condições extremas às quais os habitantes das regiões próximas ao polo norte se adaptam e, portanto, que enfrentaram também os exploradores. A ciência se torna aqui motor e motivação para superar os maiores desafios e, sobretudo, é exaltada a sua dimensão heróica.

A presença sueca no mundo afora, de uma ordem totalmente diferente e sem a dimensão épica da expedição liderada por Nordenskiöld, é também atestada no Congo, dessa vez ilustrada através da cenografia de uma missão: uma mesa redonda e cadeiras, com livros abertos em cima, sugerindo um espaço de trabalho; um expositor com forma de janela, remetendo ao tipo de arquitetura das missões; uma série de bancos de madeira frente a uma tela de projeção; cartazes de propaganda da ação das missões; fotografias dos missionários, sempre destacados com suas roupas supreendentemente brancas ${ }^{7}$ e os chapéus coloniais, junto com pessoas entre as quais desenvolviam sua ação evangelizadora; e, finalmente, os objetos coletados. O conjunto heterogêneo de objetos, sobre os quais quase nenhuma informação propriamente etnográfica é oferecida, parece ter o papel, principalmente, de atestar a ação missionária. É mais uma prova da presença sueca pelo mundo.

Na contiguidade do trecho dedicado à missão, há uma parte titulada "Whose objects?" onde são expostos diversos objetos de bronze do antigo reino de Benin, sendo que a expografia demonstra uma clara intenção de destacar suas qualidades plásticas. O próprio título desse segmento, inaugurado por um representante do governo nigeriano ${ }^{8}$, alude à problemática da propriedade dos objetos musealizados e coletados durante o período colonial.

O último cenário que trato aqui é o dedicado à expedição à Austrália liderada por Eric Mjöberg. O espaço reproduz o ambiente asséptico de um laboratório: paredes recobertas de azulejos brancos; luminosidade branca e fria, em contraste com a calidez e a maior escuridão dos outros espaços; expositores de formas quadradas; nenhuma outra cor além do branco e o preto. Num expositor se misturam os objetos dos integrantes da expedição e aqueles que eles coletaram entre as populações visitadas: sobre uma grande caixa que o visitante imagina ter sido usada pelos expedicionários para carregar a sua bagagem, são dispostos um machado, frutos de baobá com incisões decorativas, um ornamento ritual para a cabeça, um fonógrafo, livros, uma garrafa de vinho.... Numa parede, junto a um escudo dos aborígenes australianos, de um lado, aparece a foto da sala de trabalho de Eric Mjöberg onde esse mesmo escudo esteve pendurado junto com outros objetos coletados; do outro, a de um grupo de aborígenes com pinturas corporais. Em um pequeno canto da sala é exposto o instrumento que usou um dos expedicionários para gravar a música dos aborígenes. Mas o que mais chama a atenção nessa sala é uma grande vitrine com diversos bustos humanos, dispostos em prateleiras que formam uma grade com nichos do mesmo tamanho. Ela evoca os estudos sobre tipos físicos e as elucubrações evolucionistas sobre as raças, e não por acaso. Eric Mjöberg 
foi o líder de uma expedição que entre 1910 e 1911 explorou a região de Kimberley em Austrália, coletando centenas de espécimes da fauna e flora, assim como artefatos etnográficos (Ferrier 2006). Porém, entre os elementos coletados, uma parte significativa foram restos humanos procedentes das populações aborígenes. Orientado por um pensamento darwinista, Mjöberg considerava estas populações como o degrau mais baixo na escala evolutiva, próximas aos animais (Hallgren 2010). Os curadores, através de fotografias, objetos, textos e elementos expográficos constroem uma narrativa - intitulada "Eric Mjöberg: Skeleton collector" - que ilustra as diferentes faces da relação colonial. As populações aborígenes eram vítimas, simultaneamente, de um discurso econômico que sustentou a sua exploração como mão de obra; de um discurso científico que as denegria com o que poderíamos chamar de "ilusão canibal"; com uma prática colecionista que levou à exumação dos restos de seres queridos e antepassados para serem levados a milhares de quilômetros. Esses restos, esquecidos durante décadas nos depósitos dos museus, foram devolvidos às populações de origem em 2004, durante uma cerimônia que se realizou no próprio Museum of Ethnography de Estocolmo (Hallgren 2010).

Em todos os contextos descritos o que se expõe é um tipo de relação instaurada através dos diversos tipos de colecionismo ocidental, em diferentes momentos e lugares. Dentre as múltiplas possibilidades de significado que os objetos expostos carregam em si, foram escolhidos aqueles que nos falam das imagens que diferentes ocidentais criaram sobre os Outros através dos seus objetos: um Outro primitivo e selvagem, bem representado pela cabeça-troféu asmat; um Outro pensado como especimen da natureza, que se confunde com a fauna; um Outro enquanto ser cultural, que através da sua tecnologia e inventividade é capaz de se adaptar aos meios mais inóspitos; um Outro passível de ser explorado, junto com o território que habita; um Outro que deve ser civilizado e salvado. Entretanto, essas imagens não falam tanto desses Outros, como de quem as produziu. No museu de etnografia de Estocolmo, os protagonistas não são os asmat, os inuit, os mbendjele ou os aborígenes australianos da região de Kimberly - ou o são apenas tangencialmente -, mas os missionários, viajantes, etnógrafos e cientistas que formaram essas coleções. A exposição é um collage de imagens; os objetos dos Outros são como espelhos que refletem, antes, a imagem de quem os coletou: cientistas, heróis, racistas... Não se trata de uma exposição sobre culturas exóticas, mas sobre as diferentes faces do colecionismo ocidental, marcado sobretudo pelo cientificismo e pelo colonialismo. Como e por que esses objetos chegaram a fazer parte do acervo de Museu? Por que essas pessoas coletavam esses objetos e sob quais princípios o faziam? O que esses objetos dizem sobre "nós" e sobre como esse "nós" se relacionou com os "outros" nos diversos contextos coloniais? Essas parecem ser as questões que orientam o percurso expositivo. 
A exposição Kanak, l'art est une parole, do Musée du Quai Branly, se apresenta como um exercício dialógico, entre Kanak e franceses, protagonistas de uma relação conflituosa cujas origens remontam à metade do século XIX. Há certo reconhecimento da culpa colonial do lado francês, mas ele é mitigado pelo predomínio da reivindicação, quase uma exaltação, cultural, artística e histórica do lado kanak. Os objetos da tradição kanak, protagonistas da exposição por sua presença quantitativamente muito superior aos outros tipos, têm, basicamente, funções artísticas e etnográficas; exercem um apelo estético ao mesmo tempo em que funcionam como elementos de reivindicação de uma herança cultural; seu caráter enquanto testemunhas e provas de um espólio, não é explorado. Na exposição, são expostos exclusivamente em tanto que objetos kanak, não enquanto objetos que no próprio ato de coleta incorporam os significados e a história dos sujeitos coloniais, que é o que parece motivar à do museu de Estocolmo.

Nada obstante, a exposição tem o grande acerto de tornar evidentes vínculos entre arte e política, ética e estética, passado, presente e futuro.... Não se trata apenas de desfrutar da beleza de objetos fascinantes; a emoção estética que a exposição produz no visitante passa e se fundamenta em sua proposta de reflexão intelectual e política. A modo de um modelo reduzido (Lévi-Strauss 1964) das relações cosmológicas e históricas em questão, a exposição constrói uma temporalidade em que o presente e o futuro têm ressonâncias no passado e vice-versa. O presente do povo kanak, em suas dimensões artísticas e políticas, remete necessariamente ao passado, ao do século XIX, mas também ao mais recente do século XX. O artista kanak Paul Wamo, numa música em que se identifica com seus antepassados, exprime essa espécie de condensação temporal e política:

“sou chamado frequentemente não civilizado, não educado; me chamam com frequência negro, selvagem [...]. Fui exposto como um animal porque era negro; expulso como um nada, porque era negro; fui tomado pelo diabo, porque não era branco..." ${ }^{\prime 9}$.

De modo pontual, a exposição traz com uma narrativa objectual o que a canção de Wamo expressa através da palavra e a música - o conflito. Porém, se na música de Wamo o conflito e a violência coloniais são expressamente denunciados, na exposição eles são o pano de fundo, um tanto difuso, a partir do qual se constrói uma narrativa em torno de outra noção não totalmente explicitada: a de reconciliação. A esse respeito, ocasião - lembremos, o referendum de independência ocorreria em breve e certamente tocaria na ferida - e conteúdo estão perfeitamente alinhados na exibição.

O colonialismo é ingrediente importante nas duas exposições, mas ocupa lugares diferentes nas narrativas. Se a exposição Kanak propõe um exercício dialógico - que poderia ser lido também, especialmente no contexto político no qual ela foi realizada, como mais um gesto de construção da paz, de superar o passado e olhar para o futuro -, "With the World in the Backpack" opta por uma autorreflexão crítica, mesmo que o grau de criticismo varie entre os diferentes segmentos do circuito, parecendo em relação a alguns personagens como Nordenskiöld mais uma exaltação do que uma crítica. Trata-se, antes de mais nada, de 
uma exposição sobre o imaginário europeu referente aos Outros, um imaginário que operou como motor e justificativa moral da empresa colonial e seus desdobramentos científicos. Trata-se de um colonialismo que não se limita à ocupação de territórios para torná-los colônias, mas de uma forma de se relacionar com o Outro que implica se apropriar dele e explorá-lo de várias formas. O colecionismo que alimentou os museus europeus - e os americanos, e os brasileiros... - foi mais um modo de apropriação, mais uma face desse colonialismo. Esse é um dos significados que os objetos portam e que ambas as exposições revelam, de diferentes formas e com argumentos diversos, sobre outros possíveis. 


\section{NOTAS}

1 Visitei ambas as exposições no período de licença para realização de pós-doutorado entre 2013 e 2014 , durante o qual recebi uma bolsa do CNPq. Além do observado durante a visita, as descrições e informações aqui apresentadas derivam da consulta de materiais produzidos sobre as exposições e do banco de dados do Museu etnográfico de Estocolmo.

2 http://www.quaibranly.fr/fr/expositions-evenements/au-musee/expositions/details-de-levenement/e/kanak-35081/

3 http://www.rfi.fr/france/20131016-kanak-musee-quai-branly-exposition-politique-culturelle

4 http://www.lemonde.fr/societe/article/2014/08/29/le-crane-de-I-insurge-atai-retourne-aux-mains-de-ses-descendantskanaks_4478873_3224.html

5 É possível acessar às informações da exposição em http://collections.smvk.se/carlotta-em/web/object/1434404

6 http://collections.smvk.se/carlotta-em/web/object/1434717

7 Não pude evitar, ao ver as fotografias, lembrar das reflexões de Taussig (2009) sobre a cor como agente colonial ao analisar as de Malinowski nas Trobriand, "[...] celebrating the aura of the man in white, glowing like a star in the depths of the darkness of the sorcerer [...] (:82). O branco deslumbrante da roupa, cor associada ao papel de administrador, não é apenas um marcador colonial para o exercício de hegemonia sobre a população indígena, mas, antes de mais nada, segundo interpreta Taussig, é um mecanismo, um tanto desesperado, para manter um sentido do corpo branco intato, um contrabalanço da sensação de dissolução provocado pela imersão na alteridade.

8 http://collections.smvk.se/carlotta-em/web/object/1520368

9 "On me nomme souvent non civilisé, non éduqué ; on me nomme souvent noir, sauvage [...]. On m’a exposé comme une bête parce que j'étais noir ; expulsé comme un rien, parce que j'étais noir ; on m'a pris pour le diable, car je n'étais pas blanc ». https://www. youtube.com/watch?v=Sb4dPGS5DzQ 


\section{REFERÊNCIAS BIBLIOGRÁFICAS}

APPADURAI, Arjun. 2008. "Introdução: Mercadorias e a política de valor". In A. Appadurai (org.) A vida social das coisas. As mercadorias sob uma perspectiva cultural. Niterói: Eduff.

BOULAY, Roger e KASARHÉROU, Emmanuel (orgs.). 2013. Kanak. L'art est une parole. Paris-Arles : Musée du Quai Branly - Actes Sud. 340 pp.

CACHON, Sophie. 2013a. "Éditorial".Télérama - Kanak Télérama - Hors-série. . 2013b. "Inventaire d'outre-mer".Télérama - Kanak Télérama - Hors-série 2013c. "L'âme des fonds".Télérama - Kanak Télérama - Hors-série.

CACHON, Sophie (org.). 2013. Télérama - Kanak Télérama - Hors-série. 98 pp.

CLIFFORD, James. 1988. "On collecting Art and Culture". In The predicament of culture. Twentieth-century ethnography, literature and art. Harvard University Press.

FABIAN, Johannes. 2001. "Curios and curiosity". In Anthropology with an attitude: critical essays. Stanford: Stanford University Press.

FERRIER, Asa. 2006. "Dr Eric Mjöberg's 1913 scientific exploration of north Queensland's rainforest region". Memoirs of the Queensland Museum 4(1): 1-27.

HALLGREN, Claes. 2010. "Eric Mjöberg and the Rethorics of Human Remains". In P. Turnbull \& Pickering, M. (orgs.) The Long Way Home: The Meaning and Values of Repatriation. London: Berghahn Books.

HELMFRID, Staffan. 2004. "Geography in Sweden". Belgeo 1.

LEIRIS, Michel. 2007. A África fantasma. São Paulo: Cosac Naify.

LÉVI-STRAUSS, Claude. 1964. El pensamiento salvaje. México : FCE

MURPHY, Maureen. 2013. "De l'art royal à l'obscénité sauvage: parcours d'une oeuvre". In Charles Ratton. L'Invention des arts "primitifs". Paris: Musée du quai Branly.

ÖSTBERG, Wilhelm (ed.). 2002. Med världen i kappsäcken: samlingarnas väg till Etnografiska museet. Estocolmo : Etnografiska museet. $409 \mathrm{pp}$.

PRICE, Sally. 2010a. "Cultures en dialogue: options pour les musées du XXle siècle". In T. Dufrêne \& Taylor, A.-C. (orgs.) Cannibalismes disciplinaires. Quand l'histoire de l'art et l'anthropologie se rencontrent. Paris: Institut national d'histoire de l'art / Musée du quai Branly.

. 2010b. "Return to the Quai Branly". Museum Anthropology 33(1)

SNOEP, Nanette Jacomijn. 2005. "La production et la transformation d'un objet ethnographique africain. Le cas de la collecte des minkisi à la fin du XIXe siècle". In M. Coquet, et al. (orgs.) Les cultures à l'oeuvre. Rencontres en art. Paris: Editions de la Maison des sciences de l'Homme.

TAUSSIG, Michael. 2009. What color is the sacred? Chicago, The University of Chicago Press.

THOMAS, Nicholas. 1991. Entangled objects. Exchange, Material Culture and Colonialism in the Pacific. Cambridge: Harvard University Press. 


\section{Colecionismo, colonialismo e museus: Ensaio sobre duas exposições}

\section{RESUMO}

O presente ensaio é uma reflexão sobre duas exposições: a exposição "Kanak, l'art est une parole", em exibição no Musée Quai Branly entre 15 de outubro de 2013 e o 26 de janeiro de 2014, e a exposição "With the World in the Backpack", em exibição permanente no Museum of Ethnography de Estocolmo. O eixo em torno do qual desenvolvo a minha reflexão é a ideia de que ambas incorporam nas suas narrativas expográficas as relações através das quais os objetos exibidos foram coletados para ser incluídos em coleções científicas e museus. De certo modo, as duas exposições condensam, paradoxalmente, a marca colonial do passado e os esforços de descolonização que definem os paradigmas através dos quais os museus olham para o futuro.

PALAVRAS-CHAVE: museus; exposições; coleções etnográficas; colonialismo.

\section{Collecting, colonialism and museums: Essay on two exhibitions}

\section{ABSTRACT}

This essay is a reflection about two exhibitions: "Kanak, l'art est une parole", exposed between 15/10/2013 and 26/01/2014, and "With the World in the Backpack", in permanent exhibition at the Museum of Ethnography of Stockholm. The central idea of my argument is that both exhibitions incorporate in their expographic narratives the relationships by which objects were collected to be included in scientific collections and museums. In a sense, the two expositions condense, paradoxically, both the colonial imprint of the past and the decolonising efforts that define the new paradigms through which museums look to the future.

KEYWORDS: museums; exhibitions; ethnographic collections; colonialism. 